Original Article

\title{
Clinical mimickers of epidermoid cyst in scalp: a retrospective histopathological study
}

\author{
Kasturi Kshitija $^{1}$, Ruchi Nagpal ${ }^{1}$, Seethamsetty Saritha ${ }^{2}$, V.Vijay Sreedhar ${ }^{1}$ \\ ${ }^{I}$ Department of Pathology, Bhaskar Medical College \& General Hospital, KNR University, Hyderabad, India \\ ${ }^{2}$ Department of Anatomy, Kamineni Academy of Medical Sciences and Research Centre, Hyderabad, India
}

\section{Keywords:}

Epidermoid cyst;

Pilomatrixoma;

Trichilemmal cyst;

Scalp;

\begin{abstract}
Background: Cystic lesions of the scalp with a clinical diagnosis of an epidermoid cyst are encountered in clinical practice. However, these lesions had a different diagnostic interpretation on histopathology examination. Therefore our study focused on the lesions clinically resembling the presentation of epidermoid cyst in the scalp region.

Materials and Methods: Forty-one cases of scalp lesions with a clinical diagnosis of epidermoid cyst over 2 years were reviewed. Details of the patients such as clinical diagnosis, age, gender, duration, gross findings, and histopathology diagnosis were obtained from the medical and histopathology records.
\end{abstract}

Results: Epidermoid cysts diagnosed both clinically and on histopathology examination accounted for $29.26 \%$ whereas the clinical mimickers constituted $70.73 \%$. The mean age of the patient was 35-years with an equal sex ratio. The commonest location was the parietal region (41.37\%). Benign and malignant lesions consisted of $97.56 \%$ and $2.4 \%$ respectively. A trichilemmal cyst was the most common clinical mimicker diagnosed.

Conclusions: Clinicians should be aware of wide differential diagnosis of epidermoid cyst in the scalp region as the management and outcome vary with each lesion. Histopathology examination proved to be a diagnostic tool in differentiating these lesions.

\section{Correspondence: \\ Dr.Ruchi Nagpal, $M D$}

Assistant Professor, Department of Pathology,

Bhaskar Medical College \& General Hospital, Hyderabad, India

ORCID ID: 0000-0003-4153-0748

Email: ruchi2001@gmail.com

Received : August $17^{\text {th }} 2020$; Accepted : April $1^{\text {st }} 2021$

Citation: Kshitija K, Nagpal R, Saitha S, Sreedhar VV. Clinical mimickers of epidermoid cyst in scalp: A retrospective histopathological study. Journal of Pathology of Nepal. 2021;11(2):1817-23. DOI: $10.3126 /$ jpn.v11i2.30678

Copyright: This is an open-access article distributed under the terms of the Creative Commons Attribution 4.0 International License, which permits unrestricted use, distribution, and reproduction in any medium, provided the original author and source are credited.

\section{INTRODUCTION}

A broad spectrum of scalp lesions is identified as painless soft tissue masses in clinical practice in all age groups. The etiology of these lesions can be inflammatory, infectious, traumatic, or neoplastic. More than $50 \%$ of these lesions are benign and cystic. Their prevalence in western countries is approximately $20 \%$. $^{1}$ There is a corresponding scarcity of data in the literature with regards to clinicopathological practice because a majority of the patients are asymptomatic and they do not pay attention to this site due to the small size of the lesions. ${ }^{2}$ Epidermoid cyst (EC) commonly presents as asymptomatic, solitary, benign cystic growth in the scalp region with a prevalence of around $7 \%$ in the head $\&$ neck region. ${ }^{3}$ Typically, these lesions do not progress to a 
size greater than $5 \mathrm{~cm}$. Benign lesions which have a similar clinical picture are trichilemmal cyst, dermoid cyst, lipoma, and capillary hemangioma. Malignant lesions have an overall prevalence of 1 to $2 \%$. Squamous cell carcinoma, basal cell carcinoma, and melanoma are known to occur in the scalp region. ${ }^{1}$ Possibilities of other common and less frequent lesions clinically resembling epidermoid cyst should be considered. Henceforth, our study is focused to ascertain the spectrum of scalp lesions mimicking the presentation of an epidermoid cyst.

\section{MATERIALS AND METHODS}

This is a retrospective study involving a total of 41 cases of scalp lesions with primary data from January 2018 to December 2019 for a duration of 2 years. Seven other cases of chronic inflammatory lesions in the scalp were excluded from the study. All the data was retrieved from the departmental records, and the histological slides were reviewed by two pathologists. The parameters included in the study were age \& gender of the patient, duration of the lesion, macroscopy findings of the excised specimen, and the histopathology diagnosis. Data was collected with the help of a proforma and managed in Microsoft Excel. All the statistical analysis was done with SPSSTM 17. Ethical approval was taken from the institutional review committee before commencing the study.

\section{RESULTS}

Out of the total 41 cases of the clinically diagnosed epidermoid cyst, only 12 cases $(29.26 \%)$ were correctly identified as epidermoid cysts both clinically as well as on histopathology examination. The rest of 29 cases (70.73\%) were misdiagnosed clinically. Benign lesions including epidermoid cyst constituted the majority of cases (40/41 cases, $97.56 \%$ ). Malignancy was seen only in one case
Table 1: Case distribution of epidermoid cyst mimickers with histopathological diagnosis

\begin{tabular}{|c|c|c|}
\hline \multirow{14}{*}{ 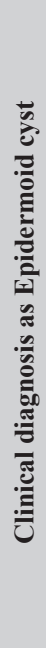 } & Histopathological diagnosis & Number $(\%)$ \\
\hline & Epidermoid cyst & $12(29.26)$ \\
\hline & Trichilemmal cyst & $12(29.26)$ \\
\hline & Dermoid cyst & $03(7.31)$ \\
\hline & Capillary hemangioma & $03(7.31)$ \\
\hline & Pyogenic granuloma & $02(4.87)$ \\
\hline & Lipoma & $02(4.87)$ \\
\hline & Pilomatrixoma & $01(2.43)$ \\
\hline & EccrinePoroma & $01(2.43)$ \\
\hline & SyringocystadenomaPapilliferum & $01(2.43)$ \\
\hline & Schwanomma & $01(2.43)$ \\
\hline & Congenital nevus & $01(2.43)$ \\
\hline & Seborrheic Keratosis & $01(2.43)$ \\
\hline & Squamous cell carcinoma & $01(2.43)$ \\
\hline
\end{tabular}

(2.40\%). The patients' age varied between 18 to 68 years with a mean age of $35 \pm$ SD. No sex predilection was seen in the lesions evaluated. From the 29 cases of mimickers of the epidermoid cyst, the commonest was a trichilemmal cyst $(12 / 29,41.37 \%)$ followed by dermoid cyst $(3 / 29$, $10.34 \%)$, capillary hemangioma $(3 / 29,10.34 \%)$, pyogenic granuloma $(2 / 29,6.89 \%)$ and lipoma $(2 / 28,6.89 \%)$. A single case $(1 / 29,3.4 \%)$ of pilomatrixoma, eccrine poroma, syringocystadenoma papilliferum, schwannoma, congenital nevus, and seborrheic keratosis were reported. Moderately differentiated squamous cell carcinoma was seen in 1 case (3.4\%) (Table 1).

The commonest region of the EC mimickers in the scalp was the parietal region $(41.37 \%)$ followed by parietooccipital $(24.13 \%)$, occipital $(20.68 \%)$, frontal $(6.8 \%)$, and temporoparietal region $(6.8 \%)$ (Table 2). The duration of

Table 2: Commonest regions of epidermoid cyst mimickers in the scalp

\begin{tabular}{|c|c|c|c|c|c|c|}
\hline Mimickers & Parietal & Parieto- Occipital & Occipital & Frontal & Tempero-Parietal & Total \\
\hline Trichilemmal cyst & 7 & 1 & 2 & & 2 & 12 \\
\hline Dermoid cyst & 1 & & & 2 & & 03 \\
\hline Capillary hemangioma & 1 & 2 & & & & 03 \\
\hline Pyogenic granuloma & & 2 & & & & 02 \\
\hline Lipoma & & & 2 & & & 02 \\
\hline Schwanomma & & 1 & & & & 01 \\
\hline Congenital nevus & & & 1 & & & 01 \\
\hline Eccrine Poroma & 1 & & & & & 01 \\
\hline $\begin{array}{l}\text { Syringocystadenoma } \\
\text { Papilliferum }\end{array}$ & 1 & & & & & 01 \\
\hline Pilomatrixoma & & 1 & & & & 01 \\
\hline Seborrheic Keratosis & 1 & & & & & 01 \\
\hline Squamous cell carcinoma & & & 1 & & & 01 \\
\hline Total & $12(41.37 \%)$ & $07(24.13 \%)$ & $06(20.68 \%)$ & $02(6.8 \%)$ & $02(6.8 \%)$ & $29(100 \%)$ \\
\hline
\end{tabular}




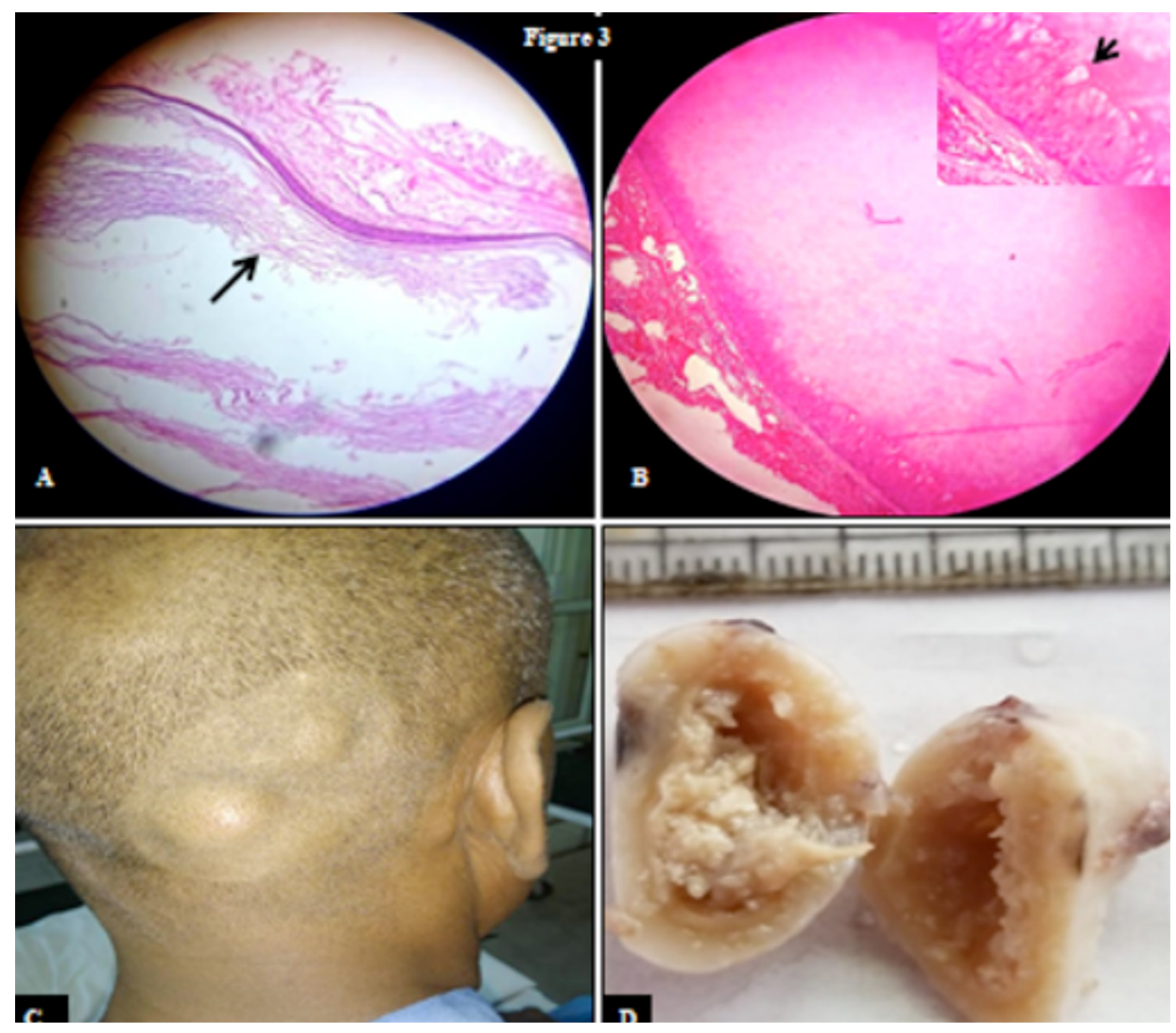

Figure 1A: Epidermoid cyst with keratin flakes (black arrow; HE stain, X40) 1B: Trichilemmal cyst with homogenous keratin inset shows swollen cells (black arrow) close to keratin and no granular layer (HE stain, X100). 1C: Clinical photograph of Trichilemmal cyst. 1D: Cut section showing trichilemmal cyst filled with pultaceous material.

the lesions varied between 4 to 10 years. The macroscopic size ranged from $0.5 \mathrm{~cm}$ to $4.5 \mathrm{cms}$. On histopathology, the EC was lined by stratified squamous epithelium and the cystic cavity contained keratin flakes (fig. 1A).

The cyst wall of the trichilemmal cyst was lined by stratified squamous epithelium without intervening granular layer and contained homogenous eosinophilic keratin (fig. 1B). Sebaceous glands and hair shafts were seen in addition to the stratified squamous epithelium in dermoid cysts (fig. 2A). Syringocystadenomapapilliferum exhibited cystic invagination in the dermis lined by keratinizing squamous epithelium. The papillary projections into the cysts were lined by luminal columnar cells with decapitations and abluminal cuboidal cells (fig. 2B). Eccrine poroma had broad anastomosing bands of benign epithelial cells in the dermis (fig. 2C). Epithelial islands in the dermis with an abrupt transition from basophilic cells to shadow cells embedded in the cellular stroma were seen in pilomatrixoma (fig. 2D). Lobules of closely packed capillaries lined by endothelial cells were seen in capillary hemangioma (fig. 3A). Pyogenic granuloma showed a lobular pattern of vascular proliferation with inflammation and skin ulceration (fig. 3B). Mature adipose tissue arranged in lobules interspersed with fibrous tissue was given as fibro lipoma (fig. 3C). Schwannoma showed hypercellular Antoni A areas with compact fascicles of spindle-shaped cells and Verocay bodies alternating with myxoid hypocellular Antoni B areas (fig. 3D). Congenital nevus revealed type A, B, C nevus cells in papillary and reticular dermis extending around adnexa with junctional activity (fig. 4A,B). Acanthotic type of seborrheic keratosis revealed hyperkeratosis, papillomatosis along invagination of the epidermis into broad bands and columns of basaloid cells with pigmentation and pseudo-horn cysts (fig. 4C). Moderately differentiated squamous cell carcinoma with individual cell keratinisation was also reported (fig. 4D).

\section{DISCUSSION}

Clinicians face a diagnostic dilemma in accurately identifying scalp cysts and tumors preoperatively. The frequency of surgeons and dermatologists obtaining an appropriate clinical diagnosis was found to be $13 \%$ to $27 \% .{ }^{2}$ In our study, these painless lesions had varied clinical presentations like sessile, macule to a nodule in appearance and soft to firm in consistency. Mild reddish to brownish discoloration and ulceration of the skin were also noted in some cases. An EC and its infected counterpart can commonly present with these features making it difficult for the clinicians to know the true nature of its mimickers. This was the reason for the higher incidence of mimickers than EC in our study. From the patient's perceptive, the presence of these lesions can go unnoticed for a very long period of time. The possibilities for this, are the discreet location 


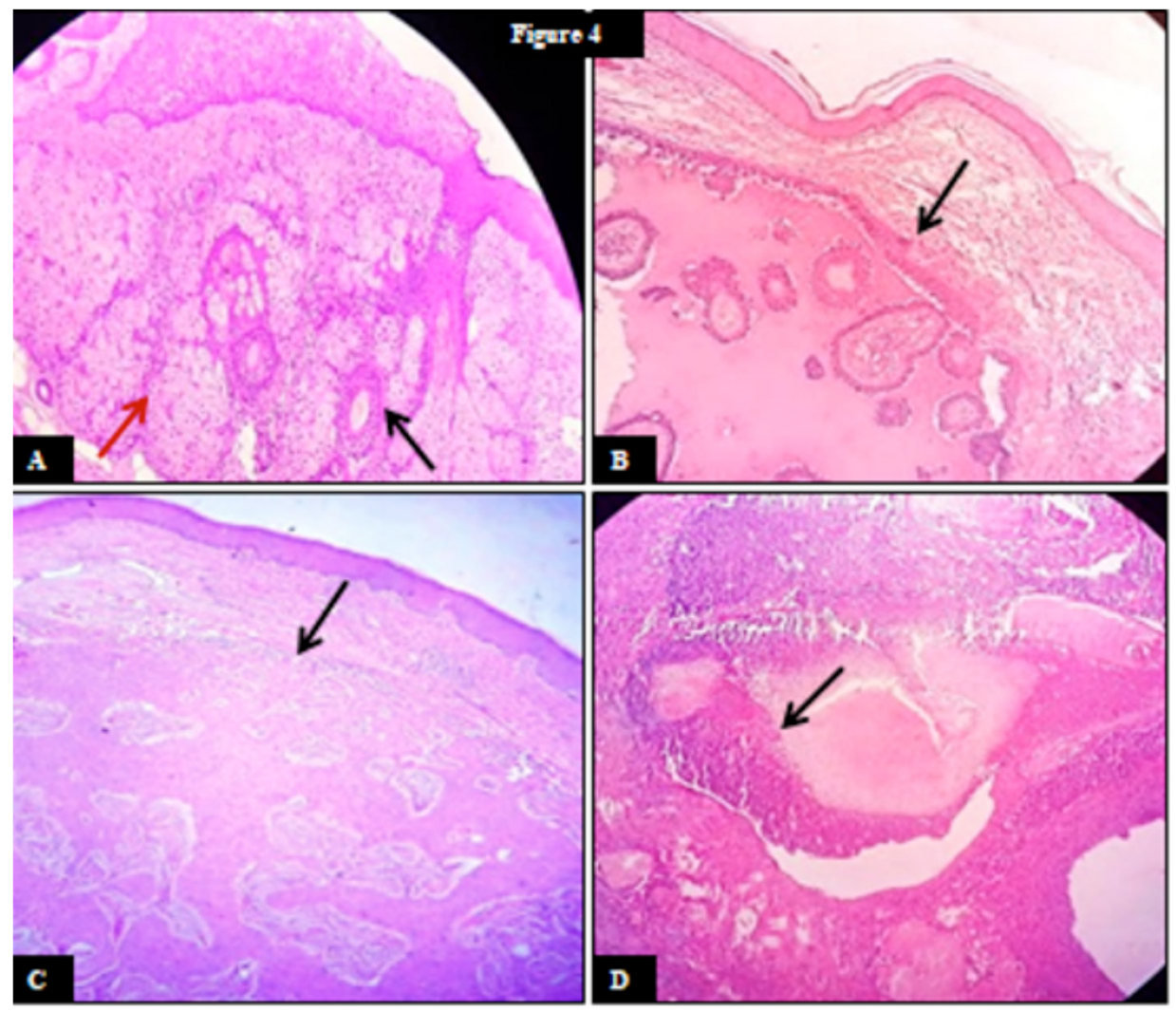

Figure 2A: Dermoid cyst with sebaceous gland (red arrow) and hair shaft (black arrow) 2B: Syringocystadenoma Papilliferum showing cystic invagination in the dermis(black arrow) $2 C$ : EccrinePoroma showing broad anastomosing bands of benign epithelial cells in the dermis (black arrow). 2D: Pilomatrixoma showing epithelial islands in the dermis with abrupttransition (black arrow) from basophilic cells to shadow cells.(HE stain, X100)

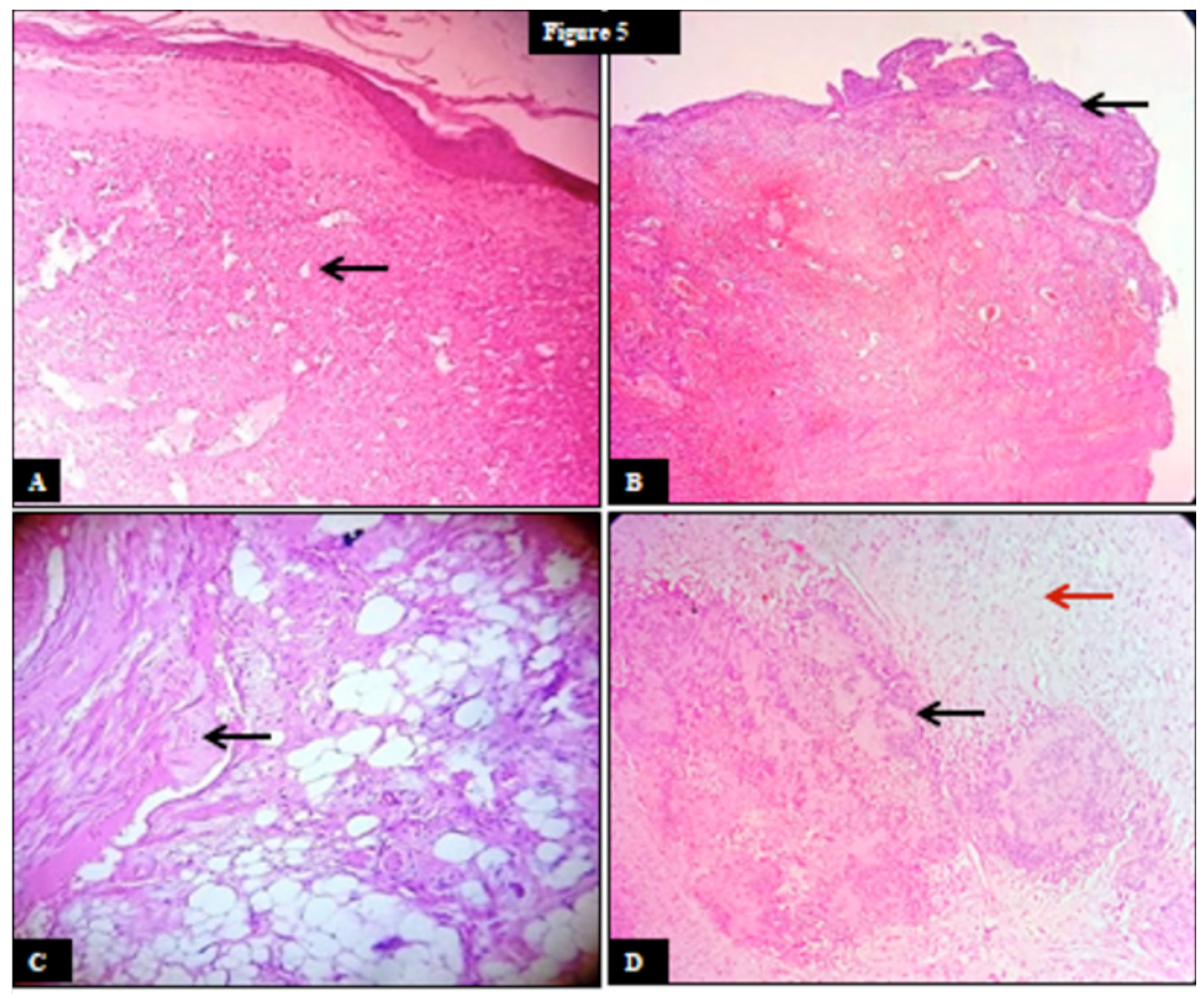

Figure: 3A: Capillary haemangioma showing lobules of closely packed capillaries (black arrow) 3B: Pyogenic granuloma showing vascular proliferation and skin ulceration (black arrow) 3C: Fibrolipoma showin globules of mature adipose tissue with fibrous bands (black arrow) 3D: Schwannoma with Antoni $A$ and $B$ areas (black and red arrows respectively), (HE stain, X100) 


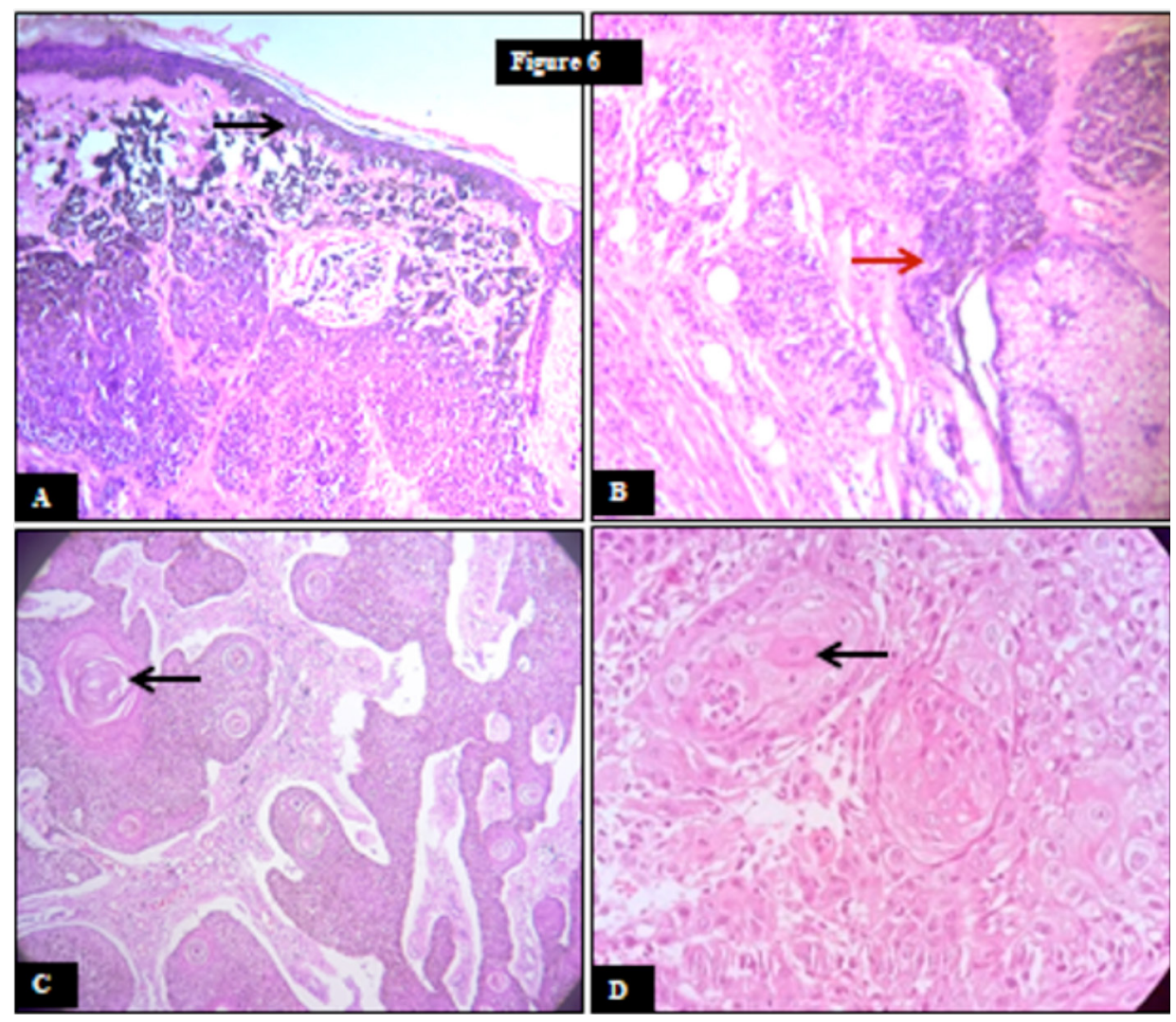

Figure 4A: Congenital nevus showing showed Type A, B, C nevus cells in dermis with junctional activity (Black arrow; HE stain, X100).4B: Nevus cells are seen extending around adnexa (Red arrow; HE stain, X200) 4C: Acanthotic seborrheic keratosis showing pseudohorn cysts (Back arrow; HE stain, X100) 4D: Moderately differentiated squamous cell carcinoma with individual cell keratinisation (Black arrow; HE stain, X200)

in the scalp, poor visibility of the lesion which is mostly covered by hair, and ignorance on the part of the patient as it will be small in size in the initial phase. The abovementioned factors are responsible for the late presentation of the scalp lesions. In our study also the duration of the lesion given by the patients ranged between 4 to 10 years.

With regard to scalp lesions, the majority of them are cystic and benign in origin, the commonest being an epidermoid cyst.4In our study also, an identical observation was made. The frequency of EC and TC was equal in our study. Hence, TC or pilar cyst was the commonest lesion that resembled the clinical presentation of EC. TC accounted for 30\% of all the benign lesions in our study which correlates with a study done by Mane et al where the incidence was 36\%. ${ }^{5}$ Another study done by Kilitci et al, also mentioned the similar incidence of TC as $38.7 \% .^{6} \mathrm{TC}$ is produced by budding of outer root sheath of the isthmus of the follicle whereas EC arises from the follicular infundibulum. The two cystic lesions have to be differentiated as TC accounts for $90 \%$ of cystic lesions in the scalp due to its tendency to occur in high hair follicle concentration. They present as multiple, slow-growing, non-tender intradermal or subcutaneous nodules on the scalp. Solitary lesions are seen in $30 \%$ of the cases. ${ }^{7}$ In our study all the patients had solitary, slow-growing, and non-tender presentations. TC needs a wider excision to avoid recurrence or progression to more aggressive proliferating trichilemmal tumor which can undergo malignant transformation.8Till now malignancy in proliferating trichilemmal tumors has been reported in approximately 30 cases. $^{9}$ The dermoid cyst not only shares the same location as EC in the midline but also in the frequency which is 1.6 to $6.9 \%$ in the head and neck region. ${ }^{10}$ It occurs as a consequence of traumatic implantation or persistence of ectodermal elements along the lines of suture closure in adults. Even though both these cysts are lined by stratified squamous epithelium, adnexal structures are seen in the dermoid cyst and not in EC. In our study we reported 3 cases of dermoid cyst which is comparable with the study done by Mane et al in which 4 cases were documented. ${ }^{5}$ It has to be thoroughly excised as the rate of recurrence in an infected cyst in the previous studies was seen to be $20 \% .{ }^{11}$ Malignant transformation was observed in $2 \%$ of the cases. ${ }^{10}$

Soft tissues tumors such as vascular tumor, lipoma, and schwannoma also mimic EC clinically. Our study also included eight cases of these soft tissue tumors. According to Kapuriya et al, the most common site for vascular tumors was the head and neck region accounting for $67 \%$ of all the cases. ${ }^{12}$ Among the vascular tumors, capillary hemangioma, and pyogenic granuloma were more in number. It is perhaps due to the rich vascularity of this region. In our study vascular tumors constituted $12.14 \%$ of the total cases. Mane et al encountered 7 cases of vascular tumors $(9.09 \%)$ among 77 cases of scalp lesions and Chaudhary PK encountered 
8 cases (12.3\%) among 65 such cases in their studies. ${ }^{5,13}$ Lipoma occurs at the frequency of $5 \%$ to $14.5 \%$ in the scalp as documented by one study ${ }^{6}$. We had a single case of lipoma and fibrolipoma each accounting for $4.8 \%$ of the total cases. Our study had a lower incidence of lipomas as compared to Mane et al and Leena et al who have observed $11.7 \%$ and $10.9 \%$ respectively but were comparable to the incidence of $5.5 \%$ reported by Carson et al. ${ }^{5,14,15}$ Schwannoma are rarely encountered in the scalp. It has to be considered as a differential diagnosis for cystic tumors on the scalp as few cases of malignant transformation to malignant peripheral nerve sheath tumor have been reported in the scalp in other studies. ${ }^{16}$ We had a single case of schwannoma which clinically mimicked EC. Mane et al also had a similar clinical scenario in their study. ${ }^{5}$

With reference to cutaneous adnexal tumors, Sharma et al in their study experienced that majority of these tumors were benign in origin accounting for $80.36 \%$ of the total cases studied. ${ }^{17}$ Similarly, Samaila also reported an incidence of $88.5 \%$ of benign adnexal tumors in their study. ${ }^{18}$ Our study had 3 cases of adnexal tumors and all were benign in nature. These tumors have varied clinical presentation and are relatively less frequent on the scalp. According to Sharma et al, the location of adnexal tumors in the scalp region was found out to be $21.43 \%$ of all the cases. ${ }^{17} \mathrm{In}$ another study done by Saha et al, the incidence of adnexal tumors was found to be $0.08 \%$ in head and neck region. ${ }^{19}$ Due to its low-frequency rate they are more often than not misdiagnosed preoperatively by the clinicians because of less experience in such cases. In Samaila's study on cutaneous adnexal tumors, only 2 out of a total of 52 cases had a clinical diagnosis of adnexal tumor. ${ }^{18}$ In our study all three cases had a clinical diagnosis of EC. We report one case of eccrine poroma which originates from the sweat gland of the epidermis. Its occurrence in the scalp is very rare and up till now, only 18 cases have been reported. ${ }^{20} \mathrm{We}$ also report one case of syringocystadenoma papilliferum. It arises from pluripotent cells of apocrine lineage. At birth, it is seen in $50 \%$ of cases, and in 15 to $30 \%$ of the cases, it is seen before puberty. ${ }^{21}$ Conversely in our study the age of presentation was 32 years. It has to be completely excised to prevent its progression to its malignant counterpart which till now nearly 30 cases has been documented. ${ }^{22}$ Basal cell carcinoma is also known to develop in $10 \%$ of the cases. ${ }^{21}$ According to Lan et al the occurrence of pilomatrixoma in the scalp was found to be $16.2 \%$ of all cases, of which $27.9 \%$ were seen between 50 to 70 years of age group. ${ }^{23} \mathrm{We}$ document a single case of pilomatrixoma in 58years old male. It is ectodermal in origin and arises from the outer root sheath cell of the hair follicle. It was misinterpreted as EC both clinically as well as on cytology aspirates since it showed numerous anucleated squamous cells without ghost cells. Pant et al in their study reported two similar cases which were misdiagnosed on cytological aspirates. ${ }^{24}$ It is necessary to do a wide excision of this tumor with a $5 \mathrm{~mm}$ clearance margin to prevent recurrence which is seen in
$14 \%$ of cases and also progression to pilomatrix carcinoma which till now 90 cases are reported in the literature, half of which were in head and neck region. ${ }^{25}$

Sometimes pigmented nodular lesions in the scalp can be mistaken for EC as pigmentation may not be evident in dark-skinned people. We encountered two such cases in our study. One was a case of seborrheic keratosis which constituted $2.4 \%$ of all the scalp lesions. The incidence rate correlated with the study done by Kilitci et al on scalp lesions. ${ }^{6}$ It is important to distinguish this lesion as the incidence of malignant transformation varies between $0.14 \%$ to $7 \%$, of which basal cell carcinoma is said to be common and acanthotic type is frequently transformed. ${ }^{26}$ Another was a case of small congenital nevus of less than $1.5 \mathrm{cms}$ in an occipital region which has to be clinically distinguished from EC as the risk of its transformation into melanoma is known to occur at an incidence rate of $2.6 \%$ to $4.9 \% .^{27}$

Lastly, we observed one case of malignancy with an incidence rate of $2.4 \%$ which was in concordance with the study done by Mane et al..$^{5}$ The patient was a 66 years old male who presented with a long standing history of swelling in the occipital region of 7 years duration which progressively increased in size with ulceration since 8 months. According to Chiu et al malignant scalp tumors are 4 times more common in males with common sites being occipital, temple and postauricular region. ${ }^{28}$ It occurs due to excessive exposure to UV radiation and decrease protection from it due to loss of hair especially in the elderly age group. In our study, it was clinically misdiagnosed as an infected epidermoid cyst but histology revealed moderately differentiated squamous cell carcinoma. Whether the malignancy has occurred de-novo or it arises from a preexisting epidermoid cyst was difficult to determine. The incidence of EC transforming into squamous cell carcinoma ranged between 0.011 to $0.045 \%{ }^{29}$ Frank et al literature states that 41 cases of EC located at various cutaneous sites of the body have shown transformation into squamous cell carcinoma with $7.3 \%$ of cases situated on the scalp. ${ }^{29}$ Therefore clinicians should be cautious of the fact that if EC is infected, not recovering even after a course of antibiotic treatment, or if there is a sudden onset of increase in the size are the factors responsible for the potential risk of malignant transformation.

\section{CONCLUSIONS}

Even though the frequency of epithelial tumors in the skull is $2 \%$, scalp masses presenting as EC has a wide range of histopathological features in all age groups. The majority of the scalp lesions were benign and cystic clinically mimicking EC. Hence, more mimickers were encountered and the commonest being TC. The mean age of the patient was 35 years with no sex predilection. The clinicians need to be aware of these various entities which can present as 
$\mathrm{EC}$ in the scalp region as overall prognosis, management and treatment differ. Histopathological examination of the excised specimens proved to be the gold standard in accurately diagnosing the true nature of EC mimickers.

\section{Conflict of Interest: None}

\section{REFERENCES}

1. Prodinger CM, Koller J, Laimer M. Scalp tumors. J DtschDermatolGes 2018;16:730-53. $\underline{\text { Crossref }}$

2. Türk CÇ, Bacanlı A, Kara NN: Incidence and clinical significance of lesions presenting as a scalp mass in adult patients. ActaNeurochir (Wien) 2015;157:217-23. Crossref

3. Dutta M, Saha J, Biswas G, Chattopadhyay S, Sen I, Sinha R. Epidermoid Cysts in Head and Neck: Our Experiences, with Review of Literature. Indian J Otolaryngol Head Neck Surg 2013;65:14-21. Crossref

4. Nigam JS, Bharti JN, Nair V, Gargade CB, Deshpande AH, Dey B, et al. Epidermal cysts: A clinicopathological analysis with emphasis on unusual findings.Int J Trichology 2017;9:108-12. Crossref

5. Mane AV, Patil LY, Jadhav SB.Histopathological Analysis of Scalp Lesions: Five Years Retrospective Study of Western India.Int J Contem Med Res 2017;4:1500-3 Website

6. Kilitci A, Asan Z. Histopathological Profile of Surgically Excised Scalp and Skull Lesions. Cyprus J Med Sci 2018; 3: 63-7. Crossref

7. Srinivas SM, Vittal CR, Naik M, Nagaraj C. Solitary calcified trichilemmal cyst on forearm. Int J Trichology 2013;5:163-4. Crossref

8. Sharma R, Verma P, Yadav P, Sharma S. Proliferating trichilemmal tumor of scalp: benign or malignant, a dilemma. J Cutan Aesthet Surg 2012;5:213-5. Crossref

9. Boruah DK, Gogoi BB, Prakash A, Sanyal S, Dhingani DD. Radiological and pathological evaluation of trichilemmal cysts of the scalp. J. Evid. Based Med. Healthc 2017; 4,4314-20. Crossref

10. Patel T, Patel S, Pathak J, Swain N, Jain M, Shirke KJ. Dermoid and Epidermoid Cysts: A Case Series. J Contemp Dent 2018; 8:153-6. Crossref

11. Kumar AN, Shivpuri A, Mehta S, Sambyal SS. Dermoid cyst over the left sphenoid in a child: a rare case report. Int J Otorhinolaryngol Head Neck Surg 2019;5:1688-90. Crossref

12. Kapuriya DP, Prashant P, Shah AN. Histopathological study of 100 cases of vascular tumors. National J Med Res 2012; 2:152-5. Crossref

13. Chaudhary PK. Histopathological Analysis of Scalp lesions. Saudi J. Pathol. Microbiol 2017; 2:254-7. Crossref

14. Leena JB, Sandeep MB, Saldanha C, Megha, Krishnaprasad H V. A histopathological review of scalp tumors: Hospital based study.Int J Recent TrensSci Tech 2014;12: 256-8. Crossref

15. Carson HJ, Gattuso P, Castelli MJ, Reddy V. Scalp lesions. A review of histopathologic and fine-needle aspiration biopsy findings. Am J Dermatopathol 1995;17:256-9. $\underline{\text { Crossref }}$

16. Mohan KH, Manjunath H. Cutaneous schwannoma masquerading as trichilemmal cyst over scalp in a young male. Indian J Dermatol 2013; 58:407. Crossref

17. Sharma A, Paricharak DG, Nigam JS, Rewri S, Soni PB, Omhare A et al. Histopathological study of skin adnexal tumours-institutional study in South India. J Skin Cancer 2014;2014:543756. Crossref

18. Samaila MO. Adnexal skin tumors in Zaria, Nigeria. Ann Afr Med 2008;7:6-10. Crossref
19. Saha A, Das NK, Gharami RC, Chowdhury SN, Datta PK. A clinichistopathological study of appendageal skin tumors, affecting head and neck region in patients attending the dermatology OPD of a tertiary care centre in Eastern India. Indian J Dermatol 2011; 56:336. Crossref

20. Park E, Lee DS, Eom KS. EccrinePoroma on the Scalp: A Case Report with MR Finding. The Nerve 2015; 1: 53-4. Crossref

21. Sangma MM, Dasiah SD, Bhat VR. Syringocystadenomapapilliferum of the scalp in an adult male-a case report. J Clin Diagn Res 2013;7:742-4. Crossref

22. Muthusamy RK, Mehta SS. Syringocystadenocarcinomapapilliferum with coexisting trichoblastoma: A case report with review of literature. Indian J Dermatol Venereol Leprol 2017;83:574-6. Crossref

23. Lan MY, Lan MC, Ho CY, Li WY, Lin CZ. Pilomatricoma of the head and neck: a retrospective review of 179 cases. Arch Otolaryngol Head Neck Surg. 2003;129:1327-30 Crossref

24. Pant I, Joshi SC, Kaur G, Kumar G. Pilomatricoma as a diagnostic pitfall in clinical practice: report of two cases and review of literature. Indian J Dermatol. 2010;55:390-2. Crossref

25. Liu CC, Hoy M, Matthews TW, Guggisberg K, Chandarana S. Pilomatrix carcinoma of the head and neck: Case report and literature review. Head Neck Oncol 2014;6:12. Website

26. Gupta D, Singh N, Goyal A, ToiPCh, Thappa DM. Squamous cell carcinoma in-situ and basal cell carcinoma arising from seborrheic keratosis in the same patient. Indian J Dermatol 2016; 61:126. $\underline{\text { Crossref }}$

27. Belysheva TS, Vishnevskaya YV, Nasedkina TV, et al. Melanoma arising in a giant congenital melanocytic nevus: two case reports. Diagnostic Pathol 2019;14:21. Crossref

28. Chiu CS, Lin CY, Kuo TT, Kuan YZ, Chen MJ, Ho HC et al. Malignant cutaneous tumors of the scalp: a study of demographic characteristics and histologic distributions of 398 Taiwanese patients. J Am AcadDermatol 2007;56:448-52. Crossref

29. Frank E, Macias D, Hondorp B, Kerstetter J, Inman JC. Incidental Squamous Cell Carcinoma in an Epidermal Inclusion Cyst: A Case Report and Review of the Literature. Case Rep Dermatol. 2018;10:61-8. Crossref 